\title{
Validating Interactive Flash-Based Multimedia Equipped Game of Guessing Images on Human Circulatory System in Material and Human Respiratory System for Grade VII Middle School Students
}

\author{
I F Arli ${ }^{1 *}$, Zulyusri $^{1}$ \\ ${ }^{1}$ Universitas Negeri Padang, Jl. Prof Dr. Hamka Air Tawar Barat Padang, Indonesia \\ *Corresponding author. Email: aryahanan05@gmail.com
}

\begin{abstract}
The learning by using technology is called multimedia learning. The multimedia learning is able to create interaction between teacher and the learning media, student to the learning media, and teacher to the student. The teacher's effort to develop and using learning media that follows the technology development is interactive multimedia which flash based and be equipped by guess the picture game. The aims of this research is to develop the interactive multimedia product with flash based and be equipped by guess the picture game and to discover its validity. The purpose of this study is to produce interactive flash-based multimedia equipped game guess images by research results with valid criteria. Development research using the Plomp model which. Validation of teaching materials were seen from the aspects of construction, material, graphical and language. The result shows that in construction aspect is scored 78,57\% with valid criteria, materials aspect is scored $86,90 \%$ with very valid criteria, graphical aspect is scored $78,70 \%$ with valid criteria, language aspect is scored $86,67 \%$ with very valid criteria and the average of these aspects of validation is scored $82,71 \%$ with very valid criteria. The development of interactive multimedia with flash based and be equipped by guess the picture game succeed to be developed with very valid criteria and expected to be a guidance in learning process that assisting to enhance the student's competency in the field of knowledge, behavior, and skills.
\end{abstract}

Keywords: Multimedia learning, flash-based, equipped game, human circulatory system

\section{INTRODUCTION}

Technological developments encourage the world of education to strive to renew and utilize technology in the learning process (Nurul. 2018). Ahangari and Abdollahpour (2010) state that the use of the development of science and technology can improve the quality of education. Learning that utilizes technology is called multimedia learning. Multimedia learning causes interaction between teachers and learning media, students with learning media, and teachers with students. This can be seen from Prastowo's (2011) statement that multimedia learning makes it easier for learners to control learning, choose the sequence of learning, make it easier to do tasks, and conduct evaluations independently. This problem can be overcome by the efforts of teachers to develop and utilize learning media that follow technological developments called interactive multimedia. Rusman (2012) states that interactive multimedia with games can arouse students' motivation in learning. Based on various research results it is known that interactive multimedia equipped with games has the following advantages: (1) can increase effectiveness in the learning process (Ratnawati, 2013); (2) can build psychological and sociological learners (Riber, 1996); (3) can increase the activity of students in learning (Kumar and Lightner, 2007); (4) can increase student motivation (Kronenberg, 2012).

The guessing game is a game that translates images into written forms. The advantage of guessing images is as follows: (1) balancing the right brain and left brain (right brain is more dominant image, and dominant left brain words / letters (Meier, 2001); (2) accelerating and increasing the ability to absorb subject matter; (3) increasing student motivation in learning (Lindner et al., 2017); (4) increasing the ability of students to explore knowledge in learning materials so as to improve student learning outcomes (Hanafri, 2015). 
The use of interactive multimedia equipped with android-based image guessing games cannot be maximally implemented because there is a ban on the use of android in learning in some schools. Overcoming the weaknesses of Android use needs to be developed with flash-based interactive multimedia equipped with guessing games that can be used on computer devices.

The use of flash-based interactive multimedia equipped with guessing games is deemed necessary to be developed because computer devices are sufficiently adequate in schools, but computer devices are only used in learning Computer Information Technology (ICT), try outs and Computer-Based National Exams (UNBK). This is very unfortunate because the availability of computer devices is only used at any time, even though computer devices can be used as media assistants in delivering learning materials at school.

\section{METHOD}

This research is research and the development. This study can develop products in the form of flash-based interactive multimedia equipped with guessing games that have been validated and can be used in conducting the learning process, and can improve student learning outcomes.

Development of flash-based interactive multimedia is equipped with this picture guessing game using the Plomp model (2013). Plomp's development model consists of three stages, namely the stage of initial investigation (Preliminary research), the stage of development or making a prototype (Development or prototype phase), the assessment phase (Asessment phase). The validity was assessed by expert experts, practicality was assessed based on practicality for teachers and students. But the researchers discussed only reaching the stage of validity. At the stage of the initial investigation, an analysis of the needs of students was carried out, curriculum analysis, and concept analysis. Furthermore, at the stage of developing or making a prototype, there are several steps taken which consist of prototype I, prototype II, prototype III, and prototype IV. At the assessment stage, flash-based interactive multimedia is equipped with guessing games tested with real students. In the stage of developing and manufacturing prototypes, flash-based interactive multimedia features guessing games guided by research instruments. Validity testing is done for prototype II by testing it to several expert experts. Validation of the results of the study was carried out by three expert experts. Then revisions are made based on suggestions and comments from expert experts so that flash-based interactive multimedia is equipped with guessing games that meet user needs and can be used to guide the learning process.

Validity analysis uses flash-based interactive multimedia validity data equipped with picture guessing games obtained from data collection instruments based on questionnaires filled by expert experts. Data analysis begins with determining the score for each item, determining the validation score based on the Likert scale according to Yusuf (2007):

$\begin{array}{ll}\text { Score } & \text { Category } \\ 4 & \text { Strongly Agree (SA) } \\ 3 & \text { Agree (A) } \\ 2 & \text { Disagree (D) } \\ 1 & \text { Strongly Disagree (SD) }\end{array}$

Analysis of the validity assessment on flash-based interactive multimedia equipped with guessing games in the form of construction, material, graphics, and language aspects based on the validity assessment sheet is carried out in the following steps:

Score for the answer with criteria based on Likert modified by Yusuf (2007) : 1) Decided the highest score ; 2) Highest score $=$ validator total $\mathrm{x}$ indicator total $\mathrm{x}$ maximum score; 3) Decided total score with each validator with sum up all the scores that obtained by each indicators; 4) Decided score which is obtained by sum up scores from each validator; 5) Validity score with this formula :

$$
\text { Validity Score }=\frac{\text { Total score obtained }}{\text { maximum total score }} \times 100 \%(1)
$$

6) Validity score with these criteria :

Table 1. Validity score criteria.

\begin{tabular}{|c|c|}
\hline Validity Score (\%) & Category \\
\hline $81 \%-100 \%$ & Very Valid \\
\hline $61 \%-80 \%$ & Valid \\
\hline $41 \%-60 \%$ & Quite Valid \\
\hline $21 \%-40 \%$ & Less Valid \\
\hline $0 \%-20 \%$ & Not Valid \\
\hline
\end{tabular}

\section{RESULTS}

Flash-based interactive multimedia validation is equipped with picture guessing games based on expert validation instruments based on steps for developing flash-based interactive multimedia equipped with picture guessing games, resulting in flash-based interactive multimedia equipped with guessing games such images are then validated by experts. Validators are only carried out by experts who are experts in their fields in providing an assessment of the interactive multimedia developed. flash-based interactive multimedia equipped with guessing games including aspects of construction, material aspects, aspects of 
graphics, and aspects of the Validator language that gives an assessment of this validation process is Mr. Dr. Darmansyah, ST, M.Pd as a technology expert, Dr. Abdurrahman, M.Pd as linguists, and Mr. Dr. Sumarmin Ramadhan, M.Sc as a biologist. The results of flash-based interactive multimedia equipped with guessing games are as follows.

Table 2. Construction aspects.

\begin{tabular}{|l|c|c|}
\hline \multicolumn{1}{|c|}{ Indicator } & $\begin{array}{c}\text { Validation } \\
\text { Score }(\%)\end{array}$ & Criteria \\
\hline $\begin{array}{l}\text { Flash-based interactive } \\
\text { multimedia equipped with } \\
\text { picture guessing contains } \\
\text { learning objectives that are } \\
\text { in accordance with Core }\end{array}$ & 75,00 & Valid \\
$\begin{array}{l}\text { Competencies and Basic } \\
\text { Competencies in curriculum }\end{array}$ & & \\
13 & & \\
\hline $\begin{array}{l}\text { Games in flash-based } \\
\text { interactive multimedia are } \\
\text { equipped with guessing } \\
\text { games made according to the } \\
\text { level of students' abilities }\end{array}$ & 83,33 & Highly \\
\hline $\begin{array}{l}\text { Games in flash-based } \\
\text { interactive multimedia } \\
\text { include picture guessing } \\
\text { games containing challenges } \\
\text { that can increase student } \\
\text { activity }\end{array}$ & & \\
\hline $\begin{array}{l}\text { Games in flash-based } \\
\text { interactive multimedia are } \\
\text { equipped with picture } \\
\text { guessing games that contain } \\
\text { challenges that can train } \\
\text { students to think quickly }\end{array}$ & & \\
\hline $\begin{array}{l}\text { Flash-based interactive } \\
\text { multimedia equipped with } \\
\text { picture guessing games are } \\
\text { already interactive and can } \\
\text { interact with students to the } \\
\text { fullest }\end{array}$ & & valid \\
\hline $\begin{array}{l}\text { Flash-based interactive } \\
\text { multimedia with picture } \\
\text { guessing games can improve } \\
\text { student activity in learning }\end{array}$ & & \\
\hline $\begin{array}{l}\text { Flash-based interactive } \\
\text { multimedia equipped with } \\
\text { guessing games that have } \\
\text { been made technically good }\end{array}$ & & \\
\hline
\end{tabular}

Table 3. Material aspects.

\begin{tabular}{|l|c|l|}
\hline \multicolumn{1}{|c|}{ Indicator } & $\begin{array}{l}\text { Validation } \\
\text { Score (\%) }\end{array}$ & Criteria \\
\hline $\begin{array}{l}\text { The material is in accordance } \\
\text { with Core Competencies and } \\
\text { Basic Competencies }\end{array}$ & 92,67 & $\begin{array}{l}\text { Highly } \\
\text { valid }\end{array}$ \\
\hline $\begin{array}{l}\text { Flash-based interactive } \\
\text { multimedia equipped with } \\
\text { guessing games that are made } \\
\text { right to explain the contents } \\
\text { of learning that is difficult to } \\
\text { visualize by the teacher in the } \\
\text { learning process }\end{array}$ & 91,67 & $\begin{array}{l}\text { Highly } \\
\text { valid }\end{array}$ \\
\hline $\begin{array}{l}\text { Flash-based interactive } \\
\text { multimedia equipped with a } \\
\text { game guessing the image that } \\
\text { was made to load essential } \\
\text { material }\end{array}$ & 83,33 & $\begin{array}{l}\text { Highly } \\
\text { valid }\end{array}$ \\
\hline $\begin{array}{l}\text { A concept that is difficult to } \\
\text { visualize in the form of } \\
\text { animation }\end{array}$ & 83,33 & $\begin{array}{l}\text { Highly } \\
\text { valid }\end{array}$ \\
\hline $\begin{array}{l}\text { The truth of the concept in } \\
\text { flash-based interactive } \\
\text { multimedia comes with } \\
\text { guessing games that are } \\
\text { correct }\end{array}$ & 83,33 & $\begin{array}{l}\text { Highly } \\
\text { valid }\end{array}$ \\
\hline $\begin{array}{l}\text { The depth of the material } \\
\text { presented in flash-based } \\
\text { interactive multimedia is } \\
\text { equipped with picture } \\
\text { guessing games that are } \\
\text { suitable for junior high } \\
\text { school VIII grade students }\end{array}$ & 83,33 & $\begin{array}{l}\text { Highly } \\
\text { valid }\end{array}$ \\
\hline $\begin{array}{l}\text { Presentation of material in } \\
\text { flash-based interactive } \\
\text { multimedia equipped with a } \\
\text { picture guessing game in } \\
\text { sequence }\end{array}$ & 91,67 & $\begin{array}{l}\text { Highly } \\
\text { valid }\end{array}$ \\
\hline
\end{tabular}


Table 4. Graphic aspect.

\begin{tabular}{|l|c|l|}
\hline \multicolumn{1}{|c|}{ Indicator } & $\begin{array}{l}\text { Validation } \\
\text { Score }(\%)\end{array}$ & Criteria \\
\hline $\begin{array}{l}\text { Images In flash-based } \\
\text { interactive multimedia } \\
\text { equipped with guessing } \\
\text { games the image is } \\
\text { appropriate }\end{array}$ & 83,33 & $\begin{array}{l}\text { Highly } \\
\text { valid }\end{array}$ \\
\hline $\begin{array}{l}\text { Cover letter is clear } \\
\text { Accompaniment Music is in } \\
\text { accordance with the } \\
\text { characteristics of students as } \\
\text { users }\end{array}$ & 75,00 & valid \\
\hline $\begin{array}{l}\text { Motion Pictures and } \\
\text { Animations in flash-based } \\
\text { interactive multimedia } \\
\text { equipped with interactive } \\
\text { picture guessing games have } \\
\text { delivered the learning } \\
\text { material }\end{array}$ & 83,33 & $\begin{array}{l}\text { Highly } \\
\text { valid }\end{array}$ \\
\hline $\begin{array}{l}\text { Images In flash-based } \\
\text { interactive multimedia } \\
\text { equipped with picture } \\
\text { guessing games presented in } \\
\text { the right size }\end{array}$ & 83,33 & $\begin{array}{l}\text { Highly } \\
\text { valid }\end{array}$ \\
\hline $\begin{array}{l}\text { Instructions for using flash- } \\
\text { based interactive multimedia } \\
\text { include guessing the correct } \\
\text { game }\end{array}$ & 75,00 & valid \\
\hline $\begin{array}{l}\text { Images In flash-based } \\
\text { interactive multimedia } \\
\text { equipped with guessing } \\
\text { games images can be seen } \\
\text { clearly }\end{array}$ & & \\
\hline $\begin{array}{l}\text { Letter size is appropriate and } \\
\text { can be seen clearly }\end{array}$ & 83,33 & $\begin{array}{l}\text { Highly } \\
\text { valid }\end{array}$ \\
\hline $\begin{array}{l}\text { The type of letters used are } \\
\text { correct }\end{array}$ & 75,00 & valid \\
\hline
\end{tabular}

Table 5. Languages aspect.

\begin{tabular}{|l|c|c|}
\hline \multicolumn{1}{|c|}{ Indicator } & $\begin{array}{c}\text { Validation } \\
\text { Score (\%) }\end{array}$ & Criteria \\
\hline $\begin{array}{l}\text { Languages that are in } \\
\text { accordance with the EYD } \\
\text { Indonesian rules are correct }\end{array}$ & 91,67 & $\begin{array}{c}\text { Highly } \\
\text { valid }\end{array}$ \\
\hline $\begin{array}{l}\text { Language Already Adjusted } \\
\text { to the level of understanding } \\
\text { of students }\end{array}$ & 83,33 & $\begin{array}{c}\text { Highly } \\
\text { valid }\end{array}$ \\
\hline $\begin{array}{l}\text { Languages Used Are } \\
\text { Unambiguous }\end{array}$ & 83,33 & $\begin{array}{c}\text { Highly } \\
\text { valid }\end{array}$ \\
\hline $\begin{array}{l}\text { The language used is } \\
\text { communicative }\end{array}$ & 81,67 & $\begin{array}{c}\text { Highly } \\
\text { valid }\end{array}$ \\
\hline $\begin{array}{l}\text { Consistency in the Use of } \\
\text { Terms }\end{array}$ & 83,33 & $\begin{array}{c}\text { Highly } \\
\text { valid }\end{array}$ \\
\hline
\end{tabular}

Flash-based interactive multimedia validity is equipped with guessing games obtained from the results of validation using the guideline sheet, expert validation covering construction aspects, material aspects, graphical aspects, and language aspects. On the value of validity on the construction aspect $78.57 \%$ with valid criteria. It shows that this flash-based interactive multimedia does contain learning objectives that are in accordance with core competencies and basic competencies in curriculum 13, made according to the level of ability of students, presented that will provide challenges that increase student activity, train fast thinking, and can improve competence learners.

The value of material aspect validity is $86.90 \%$ with very valid criteria. Showing that the material presented is in accordance with core competencies and basic competencies, it is made appropriate to explain the content of learning that is difficult to visualize by the teacher in the learning process, the material is essential with animated images that support, and systematic. While the value of the aspects of grafika78.70\% validity with valid criteria. Showing that the combination of images, sounds, movements of images has been presented in the right size, and the letters used have been seen clearly and the type of letters can be read. The value of the validity of the language aspects $86.67 \%$ criteria are very valid, indicating that the aspects of language are already in accordance with the EYD rules of the Indonesian language are correct, language is presented with the level of understanding of students, the language is not ambiguous and communicative.

The calculation of the overall validity value gets an average value of $82.71 \%$ with very valid criteria, so it can be concluded that flash-based interactive multimedia is equipped with picture guessing games can be used as interactive multimedia that is able to encourage active students in conducting the learning process, making it easier for students in remembering and understanding the material in the presence of flashbased interactive multimedia equipped with learning picture guessing games more easily understood and increasing students' motivation in learning.

\section{CONCLUSION}

The results of the research and discussion can be concluded that flash-based interactive multimedia is equipped with guessing games made to improve the knowledge competencies, attitude competencies, and skills competencies of students by using flash-based interactive multimedia equipped with picture guessing games. Multimedia can be used as an effective learning media in the process of learning science at the junior level in carrying out the learning process. Flash-based 
interactive multimedia equipped with guessing games developed has very valid validity values so that the multimedia that has been developed can be used in the learning process to help students in conducting learning activities, understanding available problems and achieving basic competencies to improve student competencies.

\section{REFERENCES}

[1] Ahangari, S., Abdollahpour, Z. 2010. 'The Effects of Multimedia Annotations on Iranian EFL Learners' L2 Vocabulary Learning'. The Journal of Applied Linguistics, 3(1):3-19.

[2] Hanafri, M. 2015. "Game Edukasi Tebak Gambar Bahasa Jawa Menggunakan Adobe Flash CS6Berbasis Android". Jurnal Sisfotek Global. 5 (2): 50-53.

[3] Kronenberg, F A.2012. 'Selection Criteria For Commercial Offthe-Shelf (Cots) Video Games For Language Learning'Journal of Language Learning Technologies, 42 (2):52-78.

[4] Kumar R and Lightner R.2007. "Games as an Interactive Classroom Technique: Perceptions of Corporate Trainers, College Instructors and Students". International Journal of Teaching and Learning in Higher Education, 19 (1):5363.

[5] Lindner, M, Eitel, A, Strobel, B. 2017. "Identifying Processes Underlying the Multimedia Effect in Testing: An Eyemovement Analysis. LEARNING and Instruction". journal homepage, 47 (9):102-115.

[6] Meier, D. 2001. The Accelerated Learning. Bandung: Kaifa

Nurul Ihsan, dkk. 2018. Instrumen Kecepatan Tendangan Pencak Silat Berbasis Teknologi. Jurnal Sosioteknologi 17 (1), 124-131

[7] Plomp, T. Nieveen, N. 2013. Educational Design Research Part A: An Introduction. Netherlands Institute for Curriculum development, Enschende, the Netherlands.

[8] Prastowo, A. 2011. Panduan Kreatif Membuat Bahan Ajar Inovatif. Yogyakarta: Diva Press.

[9] Ratnawati, R. 2013. Pembuatan Media Pembelajaran Biologi Untuk Kelas Sekolah Menengah Pertama Negeri 1 Tasikmadu VIII. Seminar Riset Unggulan Nasional Informatika dan Komputer FTI UNSA, 2 (1):213-225.

[10] Rieber, L. P. (1996). Seriously considering play: Designing interactive learning environments based on the blending of microworlds, simulations, and games. EducationalTechnology Research \& Development, 44(2):43-58

[11] Rusman. 2012. Belajar dan Pembelajaran Berbasis Komputer. Bandung: Alfabeta.
[12] Yusuf, M. 2007. Metodologi Penelitian. Padang: UNP Press 